\title{
DIAZEPINONE EFFECT ON LIVER TISSUE RESPIRATION AND SERUM LIPID CONTENT IN RATS WITH A ROTENONE MODEL OF PARKINSON'S DISEASE
}

\author{
L. Ya. SHTANOVA ${ }^{1,2 \bowtie}$, P. I. YANCHUK ${ }^{1}$, S. P. VESELSKY1, \\ O. V. TSYMBALYUK ${ }^{1}$, T. V. VOVKUN ${ }^{2}$, V. S. MOSKVINA', O. V. SHABLYKINA2, \\ S. L. BOGZA', V. N. BABAN ${ }^{1}$, A. A. KRAVCHENKO ${ }^{3}$, V. P. KHILYA ${ }^{2}$ \\ ${ }^{1}$ Institute of High Technologies, Taras Shevchenko National University of Kyiv, Ukraine; \\ ${ }^{2}$ Taras Shevchenko National University of Kyiv, Ukraine; \\ ${ }^{3}$ Chuiko Institute of Surface Chemistry, National Academy of Sciences, Kyiv; \\ 凶e-mail: shtanova@ukr.net
}

Received: 5 March 2020; Accepted: 13 November 2020

\begin{abstract}
Parkinson's disease (PD) is a chronic and progressive age-related neurodegenerative disorder. Accumulation of $\alpha$-synuclein aggregates, oxidative stress, mitochondrial dysfunction and lipid metabolism disturbance are thought to be the key impairments underlying PD pathogenesis. Despite long-time research, the causes of PD have not yet been clear. We investigated the influence of diazepinon, a new derivative of benzodiazepine, on liver tissue respiration (LTR), serum lipid content and behavioral parameters of rats with modeled PD induced by intraperitoneal injections of $2.0 \mathrm{mg} / \mathrm{kg}$ rotenone (ROT) within 28 days. LTR was assessed using the polarograph LP-9. Blood samples for biochemical analysis were collected from the inferior vena cava. The behavioral parameters of rats were studied by the open field test. We showed that in rats with $R O T$ - induced PD, the coefficient of liver oxygen consumption was decreased by $33.5 \%(P<0.001)$, the serum content of phospholipids, cholesterol, cholesterol esters, free fatty acids and triglycerides was reduced by 21.4\% $(P<0.001), 28.8 \%(P<0.001), 26.8 \%(P<0.001), 30.3 \%(P<0.01)$ and $41.5 \%(P<0.001)$, respectively and the motor disorders were detected. Diazepinone application resulted in a full restoration of LTR, serum concentration of phospholipids, partial recovery of serum free fatty acids and triglycerides content and significant improvement of motor behavior. However, diazepinone did not affect the reduced concentration of cholesterol and cholesterol esters in the serum of rats with simulated PD.
\end{abstract}

Ke y wo rds: Parkinson's disease, diazepinone, liver tissue respiration, serum lipids, motor behavior.

$\mathrm{P}$ arkinson's disease (PD) is a neurodegenerative disorder, which is a major health problem worldwide. Currently, PD affects $1 \%$ of the population above 60 years and approximately $4 \%$ of individuals in the highest age groups [1]. PD is a multifactorial lesion, that is characterized by motor symptoms, such as bradykinesia (slowed movement), resting tremor, rigidity and postural instability [2,3] and non-motor manifestations, including sleep disorders, and gastrointestinal, sensory, and psychiatric symptoms [4]. In a recent study, it has also been shown that a third of PD patients are affected by depression, which is combined with anxiety and apathy, further complicating the course of PD [5].
These symptoms are associated with a loss of dopaminergic neurons in the substantia nigra pars compacta of the midbrain, which results in a significant reduction in dopamine levels in the striatum. Degeneration of dopaminergic neurons has been long associated with the accumulation and aggregation of $\alpha$-synuclein in axons and synapses (in the form of so-called Lewy bodies), oxidative stress and mitochondrial dysfunction that are believed to play a major role in the etiopathogenesis of PD [6-8]. However, completely all the factors causing selective death of dopaminergic neurons have not been clearly defined, so many studies have not yet led to a clear strategy for treating PD.

(C) 2020 Shtanova L. Ya. et al. This is an open-access article distributed under the terms of the Creative Commons Attribution License, which permits unrestricted use, distribution, and reproduction in any medium, provided the original author and source are credited. 
Studies in clinical and experimental models have shown that the metabolic pathways mainly impaired in PD are related to the metabolism of lipids and energy $[9,10]$. In particular, cholesterol (CHOL) and its oxidized metabolites (oxysterols) are thought to be involved in the development of pathology such as parkinsonism [11]. Pharmacological treatment of PD is currently performed by dopamine agonists (apomorphine) and dopamine precursors (levodopa - L-dopa). These drugs are quite effective in the early stages of the disease to eliminate neuromotor disorders and inhibit the progression of parkinsonism. However, in the long run they cause some serious side effects, such as mental and motor complications [12]. In this context, the drugs with the ability to modulate mitochondrial function and biogenesis may have important clinical significance in the future treatment of PD. In recent years, the data of science literature have demonstrated in rats model of PD that in neurodegenerative disorders, such as PD, antipsychotic drugs, in particular benzodiazepine derivatives, protect the neuronal mitochondria against ROT-induced damage [13]. Benzodiazepines reduce skeletal muscle tone (effect associated with suppression of polysynaptic reflexes at spinal cord level) and demonstrate anticonvulsant activity, potentiate the action of substances that suppress the central nervous system [14].

Ukrainian scientists have synthesized the compounds of benzodiazepine group, characterized by activity relative to the CNS. Preliminary studies have shown that in rats with the ROT model of PD a new drug, 2,3-diazepine had correcting effects on liver tissue respiration and bile secretory function [15].

Some pesticides, including rotenone (ROT), have been found to inhibit complex I of the electronic transport chain, causing mitochondrial dysfunction and generation of reactive oxygen and nitrogen species that lead to oxidative stress [16]. ROT is a highly lipophilic compound that can easily cross the blood-brain barrier. It has been reported that the systemic administration of ROT could induce selective and progressive degeneration of the dopaminergic neurons and an $\alpha$-synuclein accumulation in rats, producing neuropathological features such as in patients with PD [17].

The liver plays a leading role in lipid metabolism - neutral fats, fatty acids, phospholipids, cholesterol. In healthy people, the liver consumes about $20 \%$ of oxygen from the whole body [18]. In the liver are concentrated almost all pathways of lipid metabolism, including synthesis and oxidation of higher fatty acids, lipogenesis and lipolysis, synthesis of bile acids, phospholipids (PLs), CHOL, cholesterol esters (ECHOLs). Oxygen-dependent biosynthetic processes in the liver are closely linked to energy metabolism. Since the functioning of mitochondria in neurons and hepatocytes is similar, it is important to find out, how hepatocytes mitochondria, in particular, their oxygen consumption, are involved in pathology of PD.

The purpose of this study was to investigate: 1) the features of liver functioning in rats with $P D$ modeled by ROT, in particular LTR, as well as lipid metabolism, the synthesis of which directly depends on the state of energy metabolism in hepatocytes; 2) corrective influence of the new synthetic therapeutic agent diazepinone on tissue respiration indicators and on the level of different lipids in the blood plasma of rats with PD simulated by ROT.

\section{Materials and Methods}

Compounds and reagents. ROT, dimethyl sulfoxide (DMSO) and urethane were purchased from Sigma (St. Louis, MO, USA). Thiopentalum natrium was produced in Ukraine (OAO Kyivmedpreparat).

Diazepinone - 4-(Pyridin-4-yl)-2H-benzo[d] $[1,2]$ diazepin-1 $(5 H)$-one. Elemental analysis of Diazepinone (DP) was performed in the analytical laboratory of V.P. Kukhar, Institute of Bioorganic Chemistry and Petrochemistry, NAS of Ukraine, Kyiv, Ukraine [19].

Experimental animals. Study has been done in acute experiments on 60 male mature Wistar rats (obtained from Institute of Toxicology, Academy of Medical Sciences of Ukraine (Kyiv, Ukraine), weighing 190-220 g, 14 weeks old. The animals were housed under standard conditions of humidity (55-60\%), in a temperature-controlled environment $\left(22 \pm 2^{\circ} \mathrm{C}\right)$ with a $12 \mathrm{~h}$ light/dark cycle, with unlimited access to filtered water and commercial food throughout the experimental period. Animal housing care and the application of experimental procedures were in accordance with the existing international requirements and norms of humane attitude towards animals (Strasbourg, 1986, Law of Ukraine dated February 21, 2006, No. 3447-IV) and to the decision held by Biological Ethics Committee, Educational and Scientific Centre, Institute of Biology and Medicine, National Taras Schevchenko University of Kyiv (protocol No. 3 from April 9, 2009). 
Experimental design. Rats were injected with either ROT (2.0 mg/kg, intraperitoneally (i.p.)) suspended in sunflower oil $(1 \mathrm{ml} / \mathrm{kg})$ (ROT vehicle) or vehicle alone [17], daily for 28 consecutive days (from 10:00 a.m to 12:00 a.m.). After one week, the rats were randomly divided into six groups: $1-$ Control group $(n=10)$, rats received an injection of sunflower oil $(1 \mathrm{ml} / \mathrm{kg}$ of body weight $)$ that did not include ROT; 2 - ROT group $(n=10)$, ROT $(2.0 \mathrm{mg} /$ $\mathrm{kg}) ; 3-\mathrm{ROT}+1 \%$ solution of DMSO group $(n=10)$, ROT + 1\% DMSO $(1 \mathrm{ml} / \mathrm{kg}) ; 4-\mathrm{ROT}+\mathrm{DP}$ group $(n=10), \mathrm{ROT}+\mathrm{DP}(0.5 \mathrm{mg} / \mathrm{kg}) ; 5-\mathrm{ROT}+\mathrm{DP}$ group $(n=10)$, ROT + DP $(1.0 \mathrm{mg} / \mathrm{kg}) ; 6-\mathrm{ROT}+\mathrm{DP}$ group $(n=10)$, ROT + DP $(2.0 \mathrm{mg} / \mathrm{kg})$. Immediately before use, DP was freshly suspended in a $1 \%$ DMSO solution. DP $(0.5,1.0$ and $2.0 \mathrm{mg} / \mathrm{kg})$ or $1 \%$ DMSO $(1 \mathrm{ml} / \mathrm{kg})$, were administrated daily, i.p. as a single dose, for 28 days, starting immediately after the last injection of ROT. The dose had been determined based on the lowest dose of other neuroprotective factors shown to be effective. During the experimental study period, animals from each group were weighed every seven days.

Behavioral analysis. In the ROT-treated groups, rat fur became yellow and dirty; the rats showed reduced and slow movement, tremor, rigor and an unstable gait, which were identified as PDlike symptoms [20].

Locomotor activity. The open-field test can be used to evaluate the spontaneous activity of rats. Twenty nine days following treatment rats were placed in an open field square box $(100 \mathrm{~cm}$ long, $100 \mathrm{~cm}$ wide, and $40 \mathrm{~cm}$ high), and the test area is well illuminated. The experiment was carried out in a quiet environment. Rats were video-recorded (Fotocam, Canon) for $6 \mathrm{~min}, 1 \mathrm{~min}$ for habituation and $5 \mathrm{~min}$ for behavioral analyzes. The animal was placed into the center of the bottom of the box and turn on the camera to observe for $5 \mathrm{~min}$. Two motor parameters were quantified throughout this test: locomotion frequency (number of squares crossings, defined as the number of quadrant crossings with the four paws) and rearing frequency (times the animal rise for at least $2 \mathrm{~s}$ on their rear paws in the air or against the walls). Before the test, $70 \%$ ethanol was used to thoroughly wipe the inner wall and bottom surface of the box, so as not to affect the results of the next test. Replace the animals and continue the experiment [21].

Study of LTR: measurement of oxygen tension in the liver and determination of $\mathrm{O}_{2}$ consumption by the organ. The intensity of oxygen absorption by the liver tissues was assessed by the rate of decrease in $\mathrm{pO}_{2}$ in the liver parenchyma with half a minute occlusion of the portal vein and the hepatic artery. Before the experiment, the rats were anesthetized with urethane $(1 \mathrm{~g} / \mathrm{kg}, 1 \mathrm{ml} / \mathrm{kg}$, intraperitoneally (i.p.)). Oxygen tension $\left(\mathrm{pO}_{2}\right)$ in the liver parenchyma was recorded using an LP-9 polarograph (Czech Republic). An open platinum microelectrode in glass insulation $(\mathrm{d}=0.3 \mathrm{~mm})$ with an operating voltage of $0.65 \mathrm{~V}$ was used as an indicator. A standard calomel electrode was used as a reference electrode. Several platinum electrodes were inserted into the liver, and the electrical signals from them were sent to the polarograph. To calculate the level of $\mathrm{pO}_{2}$ in the liver tissue, the method of the electrodes calibration in an environment with a known level of $\mathrm{pO}_{2}$ was applied [22] $\mathrm{pO}_{2}$ in the liver was calculated according to the equation: $\mathrm{pO}_{2}=\mathrm{pO}_{2}$ atm.Ae.Se/ (Ac.Sc), where: $\mathrm{pO}_{2} \mathrm{~atm}$ is the oxygen tension in a calibrated saline solution, balanced by an atmospheric pressure of $\mathrm{O}_{2}-150 \mathrm{mmHg}$; $\mathrm{Ac}$, Ae is the amplitude of the calibration and experimental signals (in $\mathrm{mm}$ of record); $\mathrm{Sc}$ and $\mathrm{Se}$ is the sensitivity of the polarograph scales during calibration and experiment. The rate of oxygen consumption by the liver tissue was determined by the curve of the drop in $\mathrm{pO}_{2}$ during asphyxia of the animal or occlusion of the afferent liver vessels [23]. The coefficient of oxygen consumption by the liver was calculated from this curve: $K=\lg \left(I_{1} / I_{2}\right) / 0.43 \cdot\left(t_{2}-t_{1}\right)$, where: $I_{1}$ and $I_{2}$ are the polarogram current values corresponding to $\mathrm{pO}_{2}$ at times $t_{1}$ and $t_{2}$ from the onset of asphyxia or occlusion of the liver afferent vessels. The coefficient $K$ was determined in the interval from the $10^{\text {th }}$ to the $30^{\text {th }}$ second of asphyxia or vascular occlusion.

Quantitative and qualitative determination of plasma lipids, in particular PLs, CHOL, ECHOLs, free fatty acids (FFAs) and triglycerides (TGs) was carried out by thin layer chromatography. To determine the lipid composition of the plasma, rats were anesthetized with sodium thiopental $(6 \mathrm{mg} / 100 \mathrm{~g})$ and collected 4-5 $\mathrm{ml}$ of blood from the inferior vena cava into sterile sealed tubes. Further, blood was centrifuged to separate the plasma from blood cells. Plasma lipids were separated by the method of thin layer chromatography [24].

Statistical analysis. The results were assessed by: the parametric one-way ANOVA method and also in combination with the Tukey test for pairwise comparison and $P$ values less than 0.05 were 
considered significant; the nonparametric KruskalWallis ANOVA method and also in combination with the Mann-Whitney test for pairwise comparison with Bonferroni correction and $P$ values less than 0.01 were considered significant. Statistical analysis was performed by Origin Pro 8.0, and the charts were drawn by Excel software.

\section{Results and Discussion}

Influence of DP on the LTR of rats with an experimental model of PD. The administration of ROT in rats resulted in significant inhibition of tissue respiration in the liver, as evidenced by a decrease in oxygen consumption compared to the control by $33.5 \%(P<0.001)$. In the rats of the ROT $+1 \%$ DMSO group, LTR was not fully restored, but only to $79.1 \%$ of the control $(P<0.05)$. In animals with PD that were injected the drug at doses of $0.5,1$ and $2 \mathrm{mg} / \mathrm{kg}$ the LTR indicators did not differ from the control values.

Compared with the ROT group, the ROT $+1 \%$ $\mathrm{DMSO}, \mathrm{ROT}+\mathrm{DP} 0.5 \mathrm{mg} / \mathrm{kg}$, ROT + DP $1 \mathrm{mg} /$ kg groups presented increased oxygen consumption by $22.3 \%(P<0.05), 29.8 \%(P<0.01), 40.5 \%$ $(P<0.001)$, respectively which indicated that ROT could inhibit the process of respiration in hepatocytes (Table 1).

Rats with ROT-induced model of PD have been frequently used in experiments to investigate the characteristic of PD in particular, mitochondrial dysfunction. Mitochondria are vital organelles with multiple functions, and their dysfunction can lead to decreased energy production, the formation of reactive oxygen species, and the induction of stressprovoked apoptosis. Inhibition of mitochondrial complex I causes impaired respiration and energy deficiency in the cell [25]. A complex I defect is a consistent sign of brain damage in PD, when the dopaminergic neurons of substantia nigra pars compacta are destroyed, although identical disorders are also observed in other cell types [16]. In this work, we explored the influence of ROT and DP on LTR and serum lipid concentration. Our findings revealed that DP could improve the LTR damaged by ROT in rats with simulated PD. We found that ROT decreased the coefficient of oxygen consumption in the liver of rats by a $33.5 \%$. A significant differences between the spontaneously recovered animals with PD, without DP and DP-treated rats were only found for the ROT+DP $1 \mathrm{mg} / \mathrm{kg}$ group. These results evidence that liver tissue respiration is an adequate indicator to study the effectiveness of drugs that involve in the correction of liver function, impaired in PD.

Effect of DP on rat plasma lipid concentrations in ROT-modeling $P D$. Graham SF et al. suggested that biochemical changes in the brain that occur with PD are reflected by biochemical changes in blood plasma [26]. In this study, we sought to find new biomarkers of PD, to investigate the impact of the new synthetic drug DP on them. The metabolic changes in the serum of rats in our study were mainly related to the functional state of mitochondria of hepatocytes, as well as to energy metabolism in the liver because the liver is the major organ in control of lipid homeostasis. Lipid metabolism provides the energy needed to sustain numerous biochemical transformations in the body. The hepatic enzyme systems are capable of catalyzing numerous reactions of lipid metabolism. Interestingly, H. Xicoy et al. found that lipids play a key role in most of the processes that have been associated with PD [9].

The presented data showed that the PLs content in the serum of control rats was $323.1 \pm 3.5 \mathrm{mg} \%$. Than we examined the serum of rats after 28 days of ROT administration. ROT- treated rats exhibited a decrease in plasma PLs by $21.4 \%(P<0.001)$ compared to control data. In all other groups, the PLs concentration did not have a significant differences with the results of the Control group. Compared with the ROT group, PLs concentration was significantly increased in the ROT + DP $0.5 \mathrm{mg} / \mathrm{kg}$ group and ROT + DP $1 \mathrm{mg} / \mathrm{kg}$ group: by $24 \%$ (both $P<0.05$ ) (Fig. 1).

As shown by biochemical analysis, the content of CHOL in fasting serum of control rats was $51.7 \pm 1.3 \mathrm{mg} \%$. In animals with simulated parkinsonism, the level of plasma CHOL decreased by $28.8 \%(P<0.001)$ compared with the Control group. At spontaneous recovery of rats with PD, this parameter reached $39.5 \pm 1.9 \mathrm{mg} \%$, that is by $23.6 \%$, $(P<0.001)$ less than in the Control group. DP injected at doses of $0.5,1$ and $2 \mathrm{mg} / \mathrm{kg}$ did not affect this index in rats with modeled PD, therefore the concentration of plasma $\mathrm{CHOL}$ remained lower than the control values by $38.3 \%, P<0.001$, by $31.9 \%$, $P<0.001$ and by $32.5 \%, P<0.001$ (Fig. 2 ).

An important part of the lipids that are metabolized in the liver are cholesterol esters. Serum biochemical analysis displayed that compared with the Control group, the plasma level of ECHOLs substantially decreased in the ROT group: from $63.0 \pm 1.7 \mathrm{mg} \%$ to $45.6 \pm 2.2 \mathrm{mg} \%$ or by $26.8 \%$, 
$P<0.001$. Similar results were observed in all other groups of rats. Therefore, in comparison with the Control group, the concentration of plasma ECHOL in the ROT $+1 \%$ DMSO group, in the ROT + DP $0.5 \mathrm{mg} / \mathrm{kg}$ group, in the ROT + DP $1.0 \mathrm{mg} / \mathrm{kg}$ group, in the ROT + DP $2.0 \mathrm{mg} / \mathrm{kg}$ group was lower by $28.9 \%, 31.0 \%, 30.3 \%$ and $33.4 \%$ (all $P<0.001$ ), respectively (Fig. 3).

The levels of serum FFAs also changed in rats with modeled PD. In comparision with the Control group, FFAs content in fasting plasma of rats sharply decreased in the ROT group: from $27.1 \pm 1.3 \mathrm{mg} \%$ to $18.9 \pm 1.0 \mathrm{mg} \%$, or by $30.3 \%, P<0.01$. Compared to the ROT group, the rats in the ROT + DP $2.0 \mathrm{mg} /$ $\mathrm{kg}$ group exhibited higher concentrations of FFAs by $32.3 \%(P<0.05)$ or restored by $92.1 \%$ the level of FFAs compared to the control data (Fig. 4).

As shown in Fig. 5, compared with the Control group, the ROT group exhibited significant reduction in the serum levels of TGs: by $41.5 \%(P<0.001)$. Moreover, the ROT $+1 \%$ DMSO and the ROT + DP $1.0 \mathrm{mg} / \mathrm{kg}$ groups displayed decrease in serum levels of TGs by $23.4 \%(P<0.01)$ and by $27.4 \%(P<0.05)$, respectively in comparison with the Control group. In the other groups: the ROT + DP $0.5 \mathrm{mg} / \mathrm{kg}$, the $\mathrm{ROT}+\mathrm{DP} 2.0 \mathrm{mg} / \mathrm{kg}$, comparatively with ROT group, serum TGs concentration was higher by $48.9 \%(P<0.01)$ and by $43 \%(P<0.05)$, respectively. That is, in these groups, the serum TGs content recovered by $87 \%$ and by $83.6 \%$ from the control values.

TGs play a major role as an energy substrate and a form of storage and transport of fatty acids

Ta b le 1. Effect of DP on the LTR of rats with ROTmodeled PD

\begin{tabular}{l|c}
\hline \multicolumn{1}{c|}{ Animal group } & $\begin{array}{c}\text { Coefficient of } \\
\text { liver oxygen } \\
\text { consumption (x100) }\end{array}$ \\
\hline Control & $1.82 \pm 0.07$ \\
ROT $2.0 \mathrm{mg} / \mathrm{kg}$ & $1.21 \pm 0.07^{* * *}$ \\
ROT $+1 \%$ DMSO & $1.44 \pm 0.07^{*}$ \\
ROT + DP $0.5 \mathrm{mg} \mathrm{kg}$ & $1.52 \pm 0.06$ \\
ROT + DP $1.0 \mathrm{mg} / \mathrm{kg}$ & $1.75 \pm 0.05^{\# \# \#}$ \\
ROT + DP $2.0 \mathrm{mg} / \mathrm{kg}$ & $1.57 \pm 0.08^{\#}$ \\
\hline
\end{tabular}

Means \pm SEM; $n=10 .{ }^{*} P<0.05 ; * * * P<0.001$ as compared with changes in Control group; ${ }^{*} P<0.05$, ${ }^{\# \#} P<0.001$, vs. the ROT group. ROT, rotenone; DP, diazepinone; DMSO, dimethyl sulfoxide within cells and in the plasma. Fatty acids accumulate in liver by hepatocyte blood plasma uptake and de novo biosynthesis. The metabolisms of FFAs and TGs are closely linked. In hepatocytes the FFAs are activated via acyl-CoA and transported to the mitochondria to be converted into ATP and heat as a form of energy. FFAs synthesis is an energy-dependent process. Reduced oxygen consumption by the liver tissue inhibits aerobic metabolism. Thereafter, glycolysis is activated in hepatocytes with the possible accumulation of lactic acid, which can alter the efficiency of many enzymes. In our study, we observed a significant reduction in the blood levels of FFAs in rats with PD, as well as an decrease in the concentration of TGs. Currently, there is little information about the content of FFAs in the blood at PD. A link between fatty acids intake and PD risk is controversial: one study described a positive association [27], while another reported an opposite result [28]. Serum of PD patients has decreased concentrations of long-chain polyunsaturated fatty acids, including linoleic acid, alpha-linoleic acid and arachidonic acid [29]. According to the results obtained, in the rats with PD, the serum levels of CHOL, ECHOLs and PLs were significantly reduced. First of all we associate this result with a decrease in FFAs synthesis due apparently to mitochondrial dysfunction. FFAs are key molecules for the biosynthesis of certain complex lipids. Within the hepatocyte, FFAs are esterified to glycerol-3-phosphate and to CHOL for generation of TGs or ECHOLs, respectively. FFAs

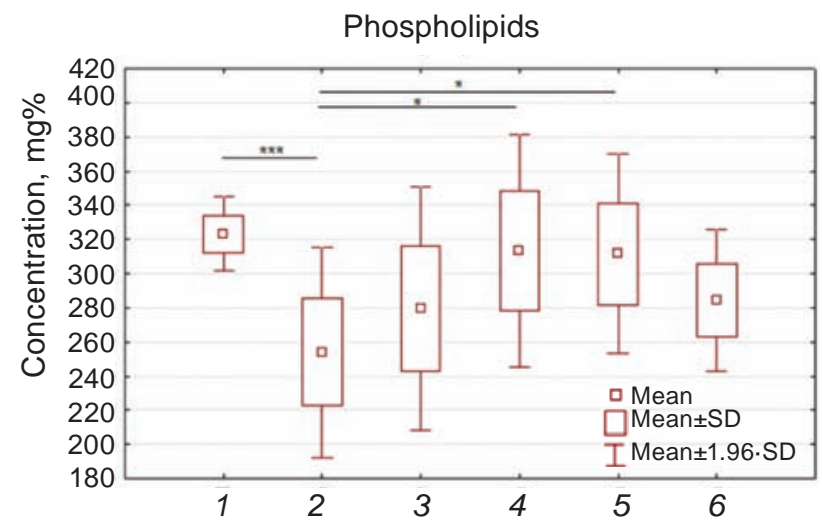

Fig. 1. Effect of DP on the concentration of PLs in the serum of rats with ROT-modeled PD. Kruskal-Wallis test. 1 -Control; $2-R O T(2.0 \mathrm{mg} / \mathrm{kg}) ; 3-R O T+1 \%$ DMSO; $4-R O T+D P(0.5 \mathrm{mg} / \mathrm{kg}) ; 5-R O T+D P$ $(1.0 \mathrm{mg} / \mathrm{kg}) ; 6-R O T+D P(2.0 \mathrm{mg} / \mathrm{kg}) . * P<0.05$ relative to $R O T$ group; $* * * P<0.001$ relative to Control group; $n=10$ 


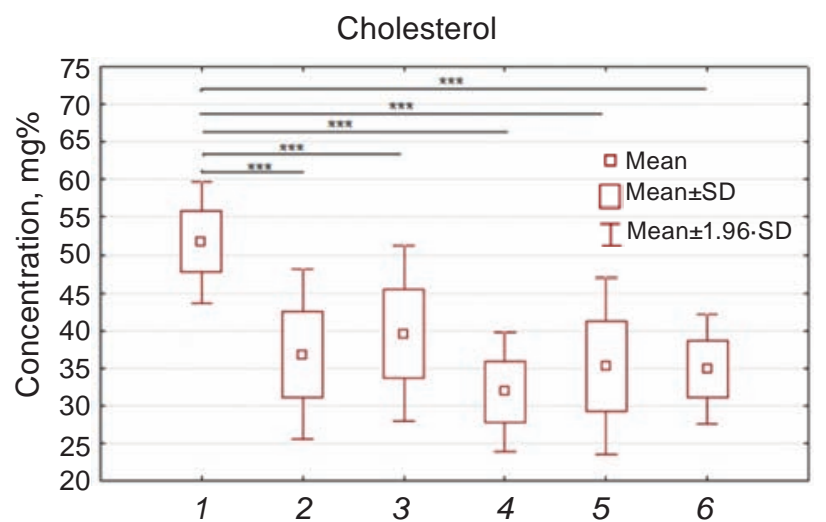

Fig. 2. Serum concentration of $C H O L$ in rats with $P D$ modeled by ROT before and after DP-treatment. 1 - Control; $2-R O T(2.0 \mathrm{mg} / \mathrm{kg}) ; 3-R O T+1 \%$ DMSO; $4-R O T+D P(0.5 \mathrm{mg} / \mathrm{kg}) ; 5-R O T+D P$ $(1.0 \mathrm{mg} / \mathrm{kg}) ; 6-R O T+D P(2.0 \mathrm{mg} / \mathrm{kg}) .{ }^{*} * * P<0.001$ relative to Control group; $n=10$

within the liver may also be used for the synthesis of PLs. Under the influence of DP (in groups ROT + DP $0.5 \mathrm{mg} / \mathrm{kg}$ and ROT + DP $1 \mathrm{mg} / \mathrm{kg}$ ) the content of serum PLs returned to the control level, indicating the protective role of the tested drug against impaired liver function caused by ROT. On the other hand, DP injection was insufficient to correct the reduced levels of CHOL and ECHOLs in the blood plasma of rats. Although, as noted above, the exact cause of $\mathrm{PD}$ is unknown, the increasing amount of literature provides evidence that circulating $\mathrm{CHOL}$ is asso-

FFAs

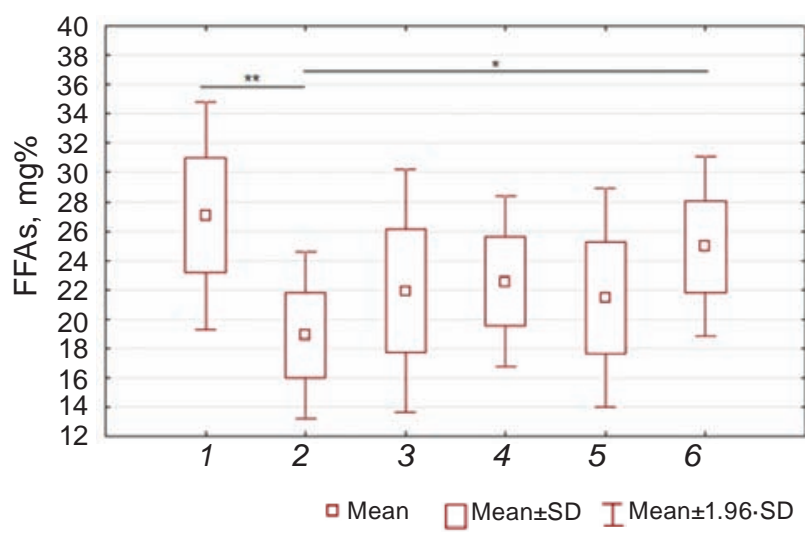

Fig. 4. Influence of DP on the concentration of FFAs in the serum of rats with ROT-modeled PD. 1 -Control; 2 - ROT $(2.0 \mathrm{mg} / \mathrm{kg}) ; 3-R O T+1 \%$ DMSO; $4-R O T+D P(0.5 \mathrm{mg} / \mathrm{kg}) ; 5-R O T+D P(1.0 \mathrm{mg} /$ $\mathrm{kg}) ; 6-R O T+D P(2.0 \mathrm{mg} / \mathrm{kg}) . * * P<0.01$ relative to Control group; $* P<0.05$ relative to $R O T$ group

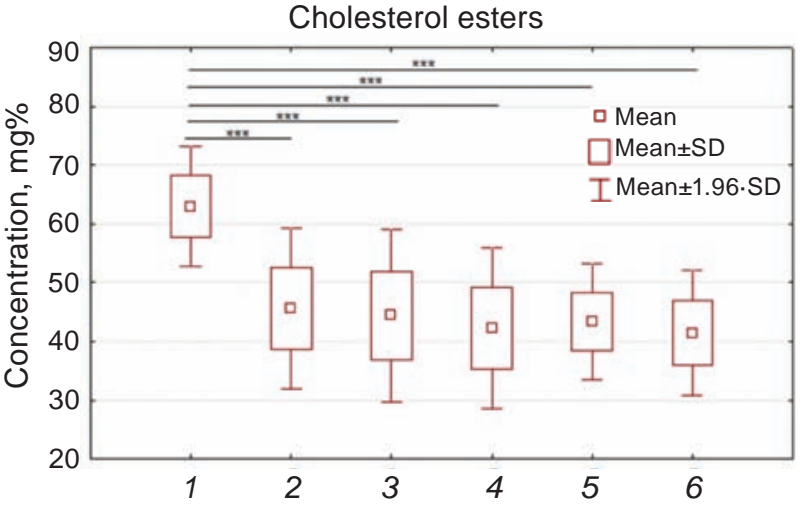

Fig. 3. The content of ECHOLs in the serum of rats with ROT-modeled PD before and after DP administration. 1 - Control; $2-R O T(2.0 \mathrm{mg} / \mathrm{kg}) ; 3-R O T+$ $1 \%$ DMSO; $4-R O T+D P(0.5 \mathrm{mg} / \mathrm{kg}) ; 5-R O T+D P$ $(1.0 \mathrm{mg} / \mathrm{kg}) ; 6-R O T+D P(2.0 \mathrm{mg} / \mathrm{kg})$. $* * * P<0.001$ relative to Control group; $n=10$

ciated with PD. The first stage of free CHOL conversion is the formation of its esters; the growth of CHOL biosynthesis is accompanied by an increase in the rate of its esterification. It is known that most tissue $\mathrm{CHOL}$ and about $65 \%$ of the plasma CHOL is esterified with higher fatty acids at position C-3. Decrease in the content of serum FFAs interrupts both the synthesis of CHOL and its esterification. The role of CHOL in the pathogenesis of PD is controversial. Most authors suggest that higher serum CHOL may be associated with lower risk of PD [30].

TGs

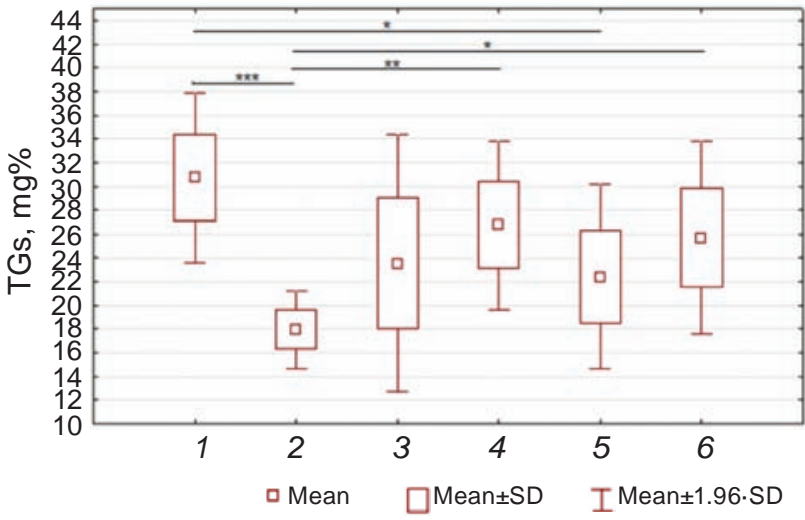

Fig. 5. Effect of DP on the concentration of TGs in the serum of rats with ROT-modeled PD. 1 - Control; $2-R O T$ (2.0 $\mathrm{mg} / \mathrm{kg}) ; 3-R O T+1 \%$ DMSO; $4-R O T+D P(0.5 \mathrm{mg} / \mathrm{kg}) ; 5-R O T+D P(1.0 \mathrm{mg})$ $\mathrm{kg}) ; 6-R O T+D P(2.0 \mathrm{mg} / \mathrm{kg}) \cdot n=10$ 
Table 2. Changing the rearing frequency in rats with ROT-modeled PD before and after DP administration (open field test was used)

\begin{tabular}{|c|c|}
\hline Animal group & Rearing frequency \\
\hline Control & $14.7 \pm 0.7$ \\
\hline ROT $2.0 \mathrm{mg} / \mathrm{kg}$ & $3.40 \pm 0.31 * * *$ \\
\hline $\mathrm{ROT}+1 \% \mathrm{DMSO}$ & $11.90 \pm 0.53^{*, \# \#}$ \\
\hline $\mathrm{ROT}+\mathrm{DP} 0.5 \mathrm{mg} / \mathrm{kg}$ & $12.5 \pm 0,5^{\# \# \#}$ \\
\hline $\mathrm{ROT}+\mathrm{DP} 1.0 \mathrm{mg} / \mathrm{kg}$ & $13.60 \pm 0,54^{\# \# \#}$ \\
\hline $\mathrm{ROT}+\mathrm{DP} 2.0 \mathrm{mg} / \mathrm{kg}$ & $12.5 \pm 0.5^{\# \# \#}$ \\
\hline
\end{tabular}

Analysis of variance (rearing frequency) marked effects are significant at $P<, 05000$. Means \pm SEM; $n=10$. ${ }^{*} P<0.05 ;{ }^{* * *} P<0.001$ as compared with changes in Control group; ${ }^{\# \# P} P<0.001$, vs. the ROT group. ROT, rotenone; DP, diazepinone; DMSO, dimethyl sulfoxide

On the other hand, it was shown that PD patients have lower CHOL than controls [31], others found no association [32] and one study suggested that elevated serum total CHOL is linked to elevated PD risk in males under 55 years of age [33].

All ROT-treated rats showed the typical behavioral features of PD: resting tremor, stiffness, upturned tip of tail, bradykinesia, or hypokinesia. Behavioral testing with the open field test indicated that the ROT group, but not the vehicle group, was affected. The present results revealed a significant decrease in rearing frequency (by $76.9 \%, P<0.001$ ) and in locomotion frequency (by $91.9 \%, P<0.001$ ) in ROT group as compared to the Control group. DPtreatment improved behavioral performance of rats with PD (Table 2, 3). In the ROT + 1\% DMSO, ROT + DP 0.5, ROT + DP 1.0 and ROT + DP $2.0 \mathrm{mg} /$ $\mathrm{kg}$ groups the incidence of locomotion did not differ from the control (Table 3).

As mentioned above, PD is associated with rest tremor, bradykinesia (slow movements), rigidity, and postural instability. We observed all these symptoms in our experimental rats by shooting them with the camera. The first symptoms of motor disorders appeared 15-17 days after the start of ROT administration. Under the influence of DP, the motor activity of rats significantly improved, in particular rats increased the frequency of hindpaws and locomotions (open field test), which may be associated with increased energy metabolism.
Table 3. Effect of DP treatment on the incidence of locomotion in rats with ROT-modeled PD (open field test was used)

\begin{tabular}{l|c}
\hline \multicolumn{1}{c}{ Animal group } & Incidence of locomotion \\
\hline Control & $33.40 \pm 0.82$ \\
ROT $2.0 \mathrm{mg} / \mathrm{kg}$ & $2.70 \pm 0.21^{* * *}$ \\
ROT $+1 \%$ DMSO & $30.7 \pm 0.5^{\# \# \#}$ \\
ROT + DP $0.5 \mathrm{mg} / \mathrm{kg}$ & $31.8 \pm 0.55^{\# \# \#}$ \\
ROT + DP $1.0 \mathrm{mg} / \mathrm{kg}$ & $31.90 \pm 0.78^{\# \# \#}$ \\
ROT + DP $2.0 \mathrm{mg} / \mathrm{kg}$ & $32.30 \pm 0.94^{\# \# \#}$ \\
\hline
\end{tabular}

Analysis of variance (rearing frequency) marked effects are significant at $P<, 05000$. Means \pm SEM; $n=10$. $* P<0.05 ; * * * P<0.001$ as compared with changes in Control group; ${ }^{\# \# P} P 0.001$, vs. the ROT group. ROT, rotenone; DP, diazepinone; DMSO, dimethyl sulfoxide

In conclusion, we demonstrated that exposure of rats to ROT inhibits tissue respiration and oxygendependent biosynthetic processes in the liver. As a result, the lipid content of the blood plasma changes. In rats with modeled PD DP improved oxygen uptake by the liver, fully or partially restored serum content of PLs, FFAs and TGs and also promoted the rapid recovery of motor activity. The decreased concentration of plasma CHOL and ECHOLs in ROT -treated rats was not influenced by DP. The features of hepatic tissue respiration and blood lipid spectrum in rats with simulated PD, as described in this paper, may provide a better understanding of the pathogenesis of parkinsonism and expose new biomarkers of mitochondrial dysfunction associated with this disease.

Conflict of interest. Authors have completed the Unified Conflicts of Interest form at http://ukrbiochemjournal.org/wp-content/uploads/2018/12/ coi_disclosure.pdf and declare no conflict of interest.

Funding. The work was performed at the Faculty of Chemistry Taras Shevchenko National University of Kyiv within the budget theme № БФ 03703 "Promising molecular tools based on natural and synthetic (carbo) heterocycles to solve problems of chemistry, medicine, industry". 


\section{ВПЛИВ ДІАЗЕПІНОНУ НА ТКАНИННЕ ДИХАННЯ ПЕЧІНКИ ТА ВМІСТ ЛІПІДІВ У СИРОВАТЦІ КРОВІ ЩУ РІВ ІЗ РОТЕНОНОВОЮ МОДЕЛЛЮ ХВОРОБИ ПАРКІНСОНА}

\author{
Л. Я. Штанова ${ }^{1,2 \bowtie}$, П. І. Янчук ${ }^{1}$, \\ С. П. Весельський \\ T. В. Вовкун ${ }^{2}$, В. С. Москвіна ${ }^{2}$, \\ О. В. Шабликіна ${ }^{2}$, С. Л. Богза $a^{2}$ В. М. Бабан ${ }^{1}$ \\ А. А. Кравченко , В. П. Хиля
}

${ }^{1}$ Інститут високих технологій, Київський національний університет імені Тараса Шевченка, Україна;

${ }^{2}$ Київський національний університет імені Тараса Шевченка, Україна;

${ }^{3}$ Інститут хімії поверхні ім. О. О. Чуйка НАН України, Київ;

凶e-mail: shtanova@ukr.net

Накопичення $\alpha$-синуклеїнових агрегатів, окислювальний стрес та мітохондріальна дисфункція вважаються ключовими в патогенезі хвороби Паркінсона (ХП). Незважаючи на багаторічні дослідження етіології ХП, причи-

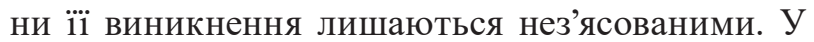
роботі досліджували вплив діазепінону, нового похідного бензодіазепіну, на тканинне дихання печінки (ТДП), вміст ліпідів у сироватці крові та характерні особливості поведінки щурів із ротеноновою моделлю ХП (в/ч ін'єкції ротенону, 2 мг/кг, впродовж 28 днів). ТДП оцінювали за допомогою полярографа LP-9. Поведінку щурів вивчали, використовуючи тест відкритого поля. Було встановлено, що введення ротенону зменшувало коефіцієнт споживання кисню печінкою на $33,5 \%(P<0,001)$, а також зменшувався вміст фосфоліпідів, холестеролу, ефірів холестеролу, вільних жирних кислот і тригліцеридів у сироватці крові - на 21,4\% $(P<0,001), 28,8 \%$ $(P<0,001), 26,8 \%(P<0,001), 30,3 \%(P<0,01)$ та 41,5\% $(P<0,001)$ відповідно. Крім цього, під впливом ротенону в щурів спостерігали розлади моторної поведінки. Застосування діазепінону значно покращувало рухову активність щурів із ХП, повністю відновлювало в них ТДП i концентрацію фосфоліпідів та частково відновлювало концентрації вільних жирних кислот і тригліцеридів у сироватці крові. Разом із тим, діазепінон не впливав на вміст холестеролу та його ефірів у сироватці крові щурів з ХП.
К л ю ч о в і с л о в а: хвороба Паркінсона, діазепінон, тканинне дихання печінки, вміст ліпідів, рухова поведінка.

\section{References}

1. Tysnes OB, Storstein A. Epidemiology of Parkinson's disease. J Neural Transm (Vienna). 2017; 124(8): 901-905.

2. Kalia LV, Lang AE. Parkinson's disease. Lancet. 2015; 386(9996): 896-912.

3. Mazzoni P, Shabbott B, Cortés JC. Motor control abnormalities in Parkinson's disease. Cold Spring Harb Perspect Med. 2012; 2(6): a009282.

4. Chaudhuri KR, Schapira AH. Non-motor symptoms of Parkinson's disease: dopaminergic pathophysiology and treatment. Lancet Neurol. 2009; 8(5): 464-474.

5. Gustafsson H, Nordström A, Nordström P. Depression and subsequent risk of Parkinson disease: A nationwide cohort study. Neurology. 2015; 84(24): 2422-2429.

6. Burré J. The synaptic function of $\alpha$-synuclein. $J$ Parkinsons Dis. 2015; 5(4): 699-713.

7. Sherer TB, Greenamyre JT. Oxidative damage in Parkinson's disease. Antioxid Redox Signal. 2005; 7(5-6): 627-629.

8. Park JS, Davis RL, Sue CM. Mitochondrial dysfunction in parkinson's disease: new mechanistic insights and therapeutic perspectives. Curr Neurol Neurosci Rep. 2018; 18(5): 21.

9. Xicoy H, Wieringa B, Martens GJM. The Role of Lipids in Parkinson's Disease. Cells. 2019; 8(1): 27.

10. Lei S, Zavala-Flores L, Garcia-Garcia A, Nandakumar R, Huang Y, Madayiputhiya N, Stanton RC, Dodds ED, Powers R, Franco R. Alterations in energy/redox metabolism induced by mitochondrial and environmental toxins: a specific role for glucose-6-phosphatedehydrogenase and the pentose phosphate pathway in paraquat toxicity. ACS Chem Biol. 2014; 9(9): 2032-2048.

11. Doria M, Maugest L, Moreau T, Lizard G, Vejux A. Contribution of cholesterol and oxysterols to the pathophysiology of Parkinson's disease. Free Radic Biol Med. 2016; 101: 393400.

12. Dorszewska J, Prendecki M, Lianeri $M$, Kozubski W. Molecular effects of L-dopa therapy in Parkinson's disease. Curr Genomics. 2014; 15(1): 11-17. 
13. Fonseca-Fonseca LA, Wong-Guerra $M$, Ramírez-Sánchez J, Montano-Peguero Y, Padrón Yaquis AS, Rodríguez AM, da Silva VDA, Costa SL, Pardo-Andreu GL, NúñezFigueredo Y. JM-20, a novel hybrid molecule, protects against rotenone-induced neurotoxicity in experimental model of Parkinson's disease. Neurosci Lett. 2019; 690: 29-35.

14. Nickel B, Jakovlev V, Szelenyi I. The effect of flupirtine, various analgesics and muscle relaxants on skeletal muscle tone in the conscious rat. Arzneimittelforschung. 1990; 40(8): 909-911.

15. Khilya VP, Yanchuk PI, Shtanova LYa, Veselsky SP, Vovkun TV, Tsymbalyuk OV, Moskvina VS, Shablykina OV, Bogza SL. The evaluation of 2.3-diazepine influence on tissue respiration of the liver and its exocrine function in rats with a rotenone model of Parkinson's disease. Biopolym Cell. 2019; 35(5): 356-370.

16. Sherer TB, Betarbet R, Testa CM, Seo BB, Richardso JR, Kim JH, Miller GW, Yagi T, Matsuno-Yagi A, Greenamyre JT. Mechanism of toxicity in rotenone models of Parkinson's disease. J Neurosci. 2003; 23(34): 10756-10764.

17. Zeng XS, Geng WS, Jia JJ. NeurotoxinInduced Animal Models of Parkinson Disease: Pathogenic Mechanism and Assessment. ASN Neuro. 2018; 10: 1759091418777438.

18. Gallagher D, Belmonte D, Deurenberg P, Wang Z, Krasnow N, Pi-Sunyer FX, Heymsfield SB. Organ-tissue mass measurement allows modeling of REE and metabolically active tissue mass. Am J Physiol. 1998; 275(2): E249-E258.

19. Shablykina OV, Krekhova OF, Konovalenko AS, Moskvina VS, Khilya VP. Interaction of 3-pyridyland 3-(imidazo[1,2-a]pyridin-2-yl) isocoumarins with hydrazine. Dopov Nac Akad Nauk Ukr. 2018; (12): 71-78.

20. Chang YT, Luo XG, Ren Y. Behavior alteration and damage of dopaminergic neurons of substantia nigra caused by rotenone in rats. Jiepouxue Yanjiu Jingzhan. 2011; 7: 60-62.

21. Bures J, Burešová $O$, Huston JP. Techniques and Basic Experiments for the Study of Brain and Behavior. Elsevier, 1976. 290 p.

22. Berezovsky VA. Oxygen tension in animal and human tissues. Kyiv: Naukova dumka, 1975. 276 p. (In Russian).
23. Tsybenko VA, Egorova LS, Mikhaylova NV, Zhakhalova LA, Dubiley TA. Neurogenic control of oxidative metabolism in the liver. Fiziol Zh SSSR Im I M Sechenova. 1988; 74(5): 737-745. (In Russian).

24. Vovkun TV, Yanchuk PI, Shtanova LYa, Veselsky SP, Filimonova NB, Komarov IV. Corvitin modulates the content of lipids in rat liver bile. Ukr Biochem J. 2019; 91(6): 112-121.

25. Panov A, Dikalov S, Shalbuyeva N, Taylor G, Sherer T, Greenamyre JT. Rotenone model of Parkinson disease: multiple brain mitochondria dysfunctions after short term systemic rotenone intoxication. J Biol Chem. 2005; 280(51): 4202642035.

26. Graham SF, Rey NL, Yilmaz A, Kumar P, Madaj Z, Maddens M, Bahado-Singh RO, Becker K, Schulz E, Meyerdirk LK, Steiner JA, Ma J, Brundin P. Biochemical profiling of the brain and blood metabolome in a mouse model of prodromal Parkinson's disease reveals distinct metabolic profiles. J Proteome Res. 2018; 17(7): 2460-2469.

27. Miyake Y, Sasaki S, Tanaka K, Fukushima W, Kiyohara C, Tsuboi Y, Yamada T, Oeda T, Miki T, Kawamura N, Sakae N, Fukuyama H, Hirota Y, Nagai M. Dietary fat intake and risk of Parkinson's disease: a case-control study in Japan. J Neurol Sci. 2010; 288(1-2): 117-122.

28. Chen H, Zhang SM, Hernán MA, Willett WC, Ascherio A. Dietary intakes of fat and risk of Parkinson's disease. Am J Epidemiol. 2003; 157(11): 1007-1014.

29. Schulte EC, Altmaier E, Berger HS, Do KT, Kastenmüller G, Wahl S, Adamski J, Peters A, Krumsiek J, Suhre K, Haslinger B, CeballosBaumann A, Gieger C, Winkelmann J. Alterations in lipid and inositol metabolisms in two dopaminergic disorders. PLoS One. 2016; 11(1): e0147129.

30. Huang $X$, Auinger P, Eberly S, Oakes D, Schwarzschild M, Ascherio A, Mailman R, Chen H. Serum cholesterol and the progression of Parkinson's disease: results from DATATOP. PLoS One. 2011; 6(8): e22854.

31. Liu JP, Tang Y, Zhou S, Toh BH, McLean C, Li H. Cholesterol involvement in the pathogenesis of neurodegenerative diseases. Mol Cell Neurosci. 2010; 43(1): 33-42. 
32. Gudala K, Bansal D, Muthyala H. Role of serum cholesterol in Parkinson's disease: a metaanalysis of evidence. J Parkinsons Dis. 2013; 3(3): 363-370.
33. Hu G, Antikainen R, Jousilahti P, Kivipelto M, Tuomilehto J. Total cholesterol and the risk of Parkinson disease. Neurology. 2008; 70(21): 1972-1979. 